\title{
Characterization of immobilized laccase from $\gamma$-proteobacterium JB: Approach towards the development of biosensor for the detection of phenolic compounds
}

\author{
Gursharan Singh, Aditya Bhalla, Neena Capalash and Prince Sharma \\ Dept. of Microbiology, Dept. of Biotechnology, Punjab University, Chandigarh 160014, India. \\ gursharan351@gmail.com; princess@pu.ac.in
}

\begin{abstract}
The two factors important when optimization of enzyme immobilization for the fabrication of biosensor are: activity and stability. The present study investigates the 2 factors when laccase was immobilized on various supports by different methods. Immobilization of partially purified laccase showed that enzyme expressed $100 \%$ activity when immobilized on the nitrocellulose membrane. $\mathrm{pH}$ and temperature optimum of immobilized laccase was 6.5 and $55^{\circ} \mathrm{C}$ respectively, when syringaldazine was used as a substrate. Immobilized laccase on nitrocellulose membrane was $100 \%$ stable at $4^{\circ} \mathrm{C}-30^{\circ} \mathrm{C}$ for three months. At $60^{\circ} \mathrm{C}$ enzyme showed $50 \%$ stability after 30 min. Immobilized laccase showed best response with syringaldazine which gave reaction even at 1 to $5 \mu \mathrm{M}$ concentration. Immobilized laccase gave response to catechol, catechin and L-methyl DOPA in the range of 40 to 90,40 to 60,30 to $70 \mu \mathrm{M}$ respectively. ABTS (2,2'-azino-bis (3-ethylbenzothiazoline-6-sulfonate)) also showed response to the laccase from 0.1 to $0.2 \mathrm{mM}$.
\end{abstract}

Keywords: Immobilization, laccase, nitrocellulose membrane, $\gamma$-proteobacterium.

\section{Introduction}

Laccases (benzenediol oxygen oxidoreductases, EC 1.10.3.2) are polyphenol oxidases that require $\mathrm{O}_{2}$ to oxidize phenols, polyphenols, aromatic amines and different non-phenolic substrates by one electron transfer resulting in the formation of reactive radicals (Gianfreda \& Bollag, 1999). They are members of the multicopper protein family that has developed from small sized prokaryotic azurins to eukaryotic ceruplasmin. Laccases are widely distributed in plants and fungi where their involvement in melanin formation and in a variety of different, and sometimes contradictory, physiological functions like fungal morphogenesis, plant pathogenesis and fungal virulence has been frequently proposed. Although, there are less reports of laccase-like activity in a few prokaryotes like Azospirillum lipoferum (Givaudan et al.,1993) Marinomonas mediterranea (Sanchez-Amat \& Solano, 1997), Bacillus subtilis spore (Hullo et al., 2001) and $\gamma$-proteobacterium JB (Bains et al., 2003).

Laccases are well known biocatalysts in transforming phenolic or aromatic amines and are considered some of the most promising enzymes for future industrial applications (Xu, 2005). Laccases from fungi and bacteria have found wide applications ranging from the pharmaceutical sector to the pulp and paper industry to reduce the kappa number and enhance the bleaching of kraft and agro waste pulp when they are used in the presence of chemical mediators, such as ABTS (Bourbonnais et al., 1997; Singh et al., 2008). In contrast to fungal laccases, bacterial laccases are overcoming the disadvantages of instability and in-process applications. Laccases from the bacteria are highly active and much more stable at high temperatures and high $\mathrm{pH}$ value Research article CIndian Society for Education and Environment (iSee)

"Immobilized laccase \& Biosensor" http://www.indjst.org
(Singh et al., 2007; Singh et al., 2008). For many continuous process applications it is necessary that used catalysts are kept in the process via immobilization. Immobilization is a proven method of enhancing the stability of enzymes in unfavourable conditions (Ahn et al., 2002). The use of a natural support medium such as clay or soil is desirable since it poses no environmental risk, and is therefore beneficial for terrestrial bioremediation. The benefits of immobilization may however be offset by the increased cost and loss of enzyme activity during immobilization (Ahn et al., 2002).

Enzymes exhibit a number of features that make their use advantageous as compared to conventional chemical catalysts. However, a number of practical problems exist that reduce their operational life-time, such as their high cost of isolation and purification, their non-reusability, the instability of their structures and their sensitivity to harsh process conditions. Many of these undesirable limitations may be overcome by the use of immobilized enzymes (Mateo et al., 2007). Compared with the free enzyme, the immobilized enzyme has usually its activity lowered and the Michaelis constant increased (Duran \& Esposito, 2000). These alterations result from structural changes introduced to the enzyme by the applied immobilization procedure and from the creation of a microenvironment in which the enzyme works, different from the bulk solution. Enzymes may be immobilized by a variety of methods (adsorption, entrapment, cross linking and covalent bonding) mainly based on chemical and/or physical mechanisms. Since the methods for the immobilization procedures greatly influence the properties of the resulting biocatalyst, immobilization strategy determines the process specifications for the catalyst. Laccase G Biosensor" Gurshan Singh et al. Indian J.Sci.Technol. 
immobilization was extensively studied (Durán \& Esposito, 2000). Herein, we reported the suitable support for the bacterial laccase. Also we investigated the response of immobilized laccase against various industrial/medically /environmentaly important analytes.

\section{Materials and methods \\ Microorganism and cultural conditions}

$\gamma$-Proteobacterium JB, isolated from industrial waste water and identified previously in our laboratory (Bains et al., 2003), was maintained as a suspension in $20 \%$ glycerol at $-70^{\circ} \mathrm{C}$ and was routinely cultured on M162 medium (Degryse et al., 1978). One $\mathrm{mL}$ of inoculum (overnight culture) was used to inoculate $100 \mathrm{~mL}$ of M162 medium, incubated at $37^{\circ} \mathrm{C}$ and $150 \mathrm{rpm}$ for $24 \mathrm{~h}$. Culture supernatant was obtained after centrifugation at $10,000 \mathrm{x}$ $\mathrm{g}, 4^{\circ} \mathrm{C}$ for $10 \mathrm{~min}$ and used as a crude extracellular enzyme having activity $7.8 \mathrm{nkat}^{-1} \mathrm{~L}^{-1}$ and specific activity 65 nkat $\mathrm{mg}^{-1}$ protein.

Partial purification of laccase (Singh et al., 2007)

Ammonium sulphate saturation was standardized by using different cuts $(0-40,40-60$ and $60-80 \%)$ of ammonium sulphate. Proteins were precipitated from the supernatant by addition of ammonium sulphate and centrifugation of salted-out proteins at $4^{\circ} \mathrm{C}, 10,000 \times \mathrm{g}$ for $20 \mathrm{~min}$. The precipitate was resuspended in $0.1 \mathrm{M}$ phosphate buffer $(\mathrm{pH} 6.5)$ and dialyzed at $4^{\circ} \mathrm{C}$ against the same buffer. The enzyme $(16.5 \mathrm{ml})$ was applied to an anion-exchange DEAE-sepharose (AmershamPharmacia Biotech, Freiburg, Germany) column (bed volume, $26.7 \mathrm{ml})$, equilibrated with $50 \mathrm{mM}$ Tris- $\mathrm{HCl}$ buffer $(\mathrm{pH}$ $8.0)$. The proteins were eluted by $\mathrm{KCl}$ gradient $(0-2 \mathrm{M}$ in equilibrating buffer) at a flow rate of $1 \mathrm{ml} \mathrm{min}^{-1}$ and $4 \mathrm{ml}$ fraction size. Fractions of laccase activity were pooled, desalted and concentrated by ultrafiltration, using $10 \mathrm{kDa}$ cut off membrane (Amicon, Millipore, USA).

\section{Entrapment of laccase in agarose-guar gum}

One $\mathrm{ml}$ each of aqueous solution of agarose $(3 \%)$ and guargum (1\%) was mixed with $1 \mathrm{ml}$ laccase (300 nkat). The mixture was spread uniformly on glass plate over the surface area $10 \mathrm{~cm}^{2}$ and kept overnight in a dust free hood for drying and stored at $4^{\circ} \mathrm{C}$ under dry conditions till further use (Tembe et al., 2007).

\section{Immobilization of laccase on nylon and nitrocellulose membranes}

Nylon general-purpose (Pall, East Hills, NY) transfer membrane presenting $50 \%$ carboxylic and $50 \%$ amine groups was used for laccase attachment. 16 nkat of laccase in $0.1 \mathrm{ml}(0.1 \mathrm{M}$ phosphate buffer $(\mathrm{pH} 6.5))$ was applied on each piece $\left(1 \mathrm{~cm}^{2}\right)$ of nylon or nitrocellulose membranes as described by Kumaran and Morita (1995). Each membrane was air dried for $10 \mathrm{~min}$ and stored at $4^{\circ} \mathrm{C}$ for further use.

Immobilization of laccase on egg shell membrane

Wen et al. (2005) described the cheapest method of immobilization of proteins on egg shell membranes and we followed this method of immobilization. Eggshell membrane was carefully peeled from a broken fresh eggshell after the albumen and yolk had been removed. It was cleaned with copious amounts of deionized water. The membrane was placed in a clean watch glass and was cut into a circle with a diameter of on $15 \mathrm{~mm}$ and 16 nkat of laccase in $0.1 \mathrm{ml}(0.1 \mathrm{M}$ phosphate buffer $(\mathrm{pH} 6.5)$ was applied on each piece of membrane. After about $1 \mathrm{~h}$, $10 \mu \mathrm{L}$ of $2.5 \%(\mathrm{w} / \mathrm{w})$ glutaraldehyde solution was added as a cross-linking agent onto the surface of the membrane. It was gently spread thoroughly on the membrane surface with a glass rod and allowed to stand for $5 \mathrm{~min}$. The membrane was then washed for $5 \mathrm{~min}$ with $0.1 \mathrm{M}$ phosphate buffer, $\mathrm{pH}$ 6.5. After washing, the laccase-immobilized eggshell membrane was stored in $0.1 \mathrm{M}$ phosphate buffer, $\mathrm{pH} 6.5$ at $4^{\circ} \mathrm{C}$ until further use.

Immobilization on polyvinyl alcohol (PVA)

Polyvinyl alcohol (20\%) was mixed with 16 nkat of laccase in the presence of $0.1 \mathrm{M}$ phosphate buffer, $\mathrm{pH}$ 6.5. After proper mixing PVA-laccase mixture was poured on a glass plate and kept under UV-light (at distance of $10 \mathrm{~cm}$ from the lamp) for 30 min for cross linking of PVA. There after $1 \mathrm{~cm}^{2}$ pieces of the membranes were cut and stored at $4^{\circ} \mathrm{C}$ for further use.

\section{Enzyme assay}

Here generally laccase activity was determined using $2 \mathrm{mM}$ guaiacol, at $55^{\circ} \mathrm{C}$ in $0.1 \mathrm{M}$ phosphate buffer $(\mathrm{pH}$ 6.5) (Bains et al., 2003). The change in absorbance due to oxidation of substrate in the reaction mixture was monitored for $10 \mathrm{~min}$ of incubation. Enzyme units were expressed in nkat (nmoles of substrate converted /second/ml of enzyme).

Spectrophotometric measurements of substrate oxidation by the crude laccase were obtained at the optimal $\mathrm{pH}$ and temperature using $4 \mathrm{ml}$ reaction mixtures containing test substrate viz., syringaldazine $(\varepsilon=50,000$ $\left.\mathrm{M}^{-1} \mathrm{~cm}^{-1}, \lambda_{\max }=525 \mathrm{~nm}\right)$, catechol $\left(\varepsilon=26,000 \mathrm{M}^{-1} \mathrm{~cm}^{-1}\right.$, $\left.\lambda_{\max }=450 \mathrm{~nm}\right)$, pyrogallol $\left(\varepsilon=35,000 \mathrm{M}^{-1} \mathrm{~cm}^{-1}, \lambda_{\max }=450\right.$ $\mathrm{nm}), p$-phenylenediamine $\left(\varepsilon=14685 \mathrm{M}^{-1} \mathrm{~cm}^{-1}, \lambda_{\max }=450\right.$ $\mathrm{nm})$, guaiacol $\left(\varepsilon=48,000 \mathrm{M}^{-1} \mathrm{~cm}^{-1} \lambda_{\max }=465 \mathrm{~nm}\right)$ or L-methyl DOPA $\left(\varepsilon=32,000 \mathrm{M}^{-1} \mathrm{~cm}^{-1}, \lambda_{\max }=475 \mathrm{~nm}\right)$. Molar absorption coefficients $(\varepsilon)$ were determined by measuring absorption of substrates after their complete oxidation by bacterial laccase.

\section{Spectrophotometric characterization of immobilized laccase}

In present study each supporting material or membrane used for immobilization of laccase was insoluble in water. Spectrophotometric analysis of immobilized protein was possible only because each membrane (egg shell, nitrocellulose, PVA, nylon and guargum-agarose) was cut in to $1 \mathrm{~cm}^{2}$ before adding in to assay mixture and thereafter shaked the test tubes after every 2 minutes for proper exposure of substrate on immobilized laccase. Prior going to read the optical density of each oxidized substrate, removed the membrane from each test tube then observed readings from spectrophotometer. For every reaction there was a 
control reaction in which only $1 \mathrm{~cm}^{2}$ supporting material or membrane was added without enzyme but with substrate and buffer. Before reaching to any conclusion each experiment was performed at least three times in same standard conditions.

pH optimum

$\mathrm{pH}$ optimum of immobilized laccase was studied using the following buffers $(0.05 \mathrm{M})$ : Citrate buffer, $\mathrm{pH}-3,4,5$ and 6; Phosphate buffer, $\mathrm{pH} \mathrm{6,} \mathrm{6.5,} 7$ and 8; Tris- $\mathrm{HCl}$ buffer, $\mathrm{pH} 7.2,8.0$ and 9.0 and Glycine- $\mathrm{NaOH}$ buffer, $\mathrm{pH}-9,10$ and 10.6. Enzyme assay was carried out at $55^{\circ} \mathrm{C}$ using syringaldazine $(5 \mu \mathrm{M})$ as the substrate.

Table 1.Comparison of various membranes for immobilization on the basis of laccase activity

\begin{tabular}{|l|c|c|}
\hline \multicolumn{1}{|c|}{ Membrane Type } & $\begin{array}{c}\text { Activity of } \\
\text { laccase } \\
\text { (nkat) }\end{array}$ & $\begin{array}{c}\% \text { loss } \\
\text { of } \\
\text { activity }\end{array}$ \\
\hline $\begin{array}{l}\text { Polyvinyl alcohol } \\
\text { membrane (PVA) }\end{array}$ & 11 & 31 \\
\hline Nylon membrane & 09 & 43 \\
\hline Nitrocellulose membrane & 16 & 0.0 \\
\hline Egg shell membrane & ND & ND \\
\hline Guargum-agarose membrane & 09 & 43 \\
\hline
\end{tabular}


detectable $100 \%$ Activity (free laccase) applied was 16 nkat

Temperature optimum

Temperature optimum of immobilized laccase was evaluated at different temperatures $\left(35-70^{\circ} \mathrm{C}\right)$. The enzyme assay was carried out at $\mathrm{pH} 6.5(0.05 \mathrm{M}$, citrate buffer) using syringaldazine $(5 \mu \mathrm{M})$ as the substrate.

Thermostability

Thermostability was checked by pre-incubating the free and immobilized laccase at $50^{\circ} \mathrm{C}, 60^{\circ} \mathrm{C}, 70^{\circ} \mathrm{C}$ for $15^{\prime}$, $30^{\prime}$ and $60^{\prime}$ 'before the enzyme assay.

Shelf life

Shelf life (0 to $60 \mathrm{~min}$ ) was determined by incubating the immobilized enzyme in $100 \mathrm{mM}$ Tris- $\mathrm{HCl}$ buffer $(\mathrm{pH} 9)$ at various temperatures i.e., $4^{\circ} \mathrm{C}$ to $60^{\circ} \mathrm{C}$. Enzyme assay was then performed with immobilized laccase at $\mathrm{pH} 6.5$. $\left(0.05 \mathrm{M}\right.$ citrate buffer) with $5 \mu \mathrm{M}$ syringaldazine at $55^{\circ} \mathrm{C}$. Recycling of the immobilized enzyme

Recycling of the results with immobilized laccase was checked at least three times for successive measurements of a known concentration of an analyte

(5 $\mu \mathrm{M}$ of syringaldazine) under standard assay conditions.

Substrate range

Activity of the immobilized laccase was checked on various substrates including medically/environmentally/ industrially important compounds like dopamine, catechin, hydroquinone, syringaldazine, ABTS, catechol, p-

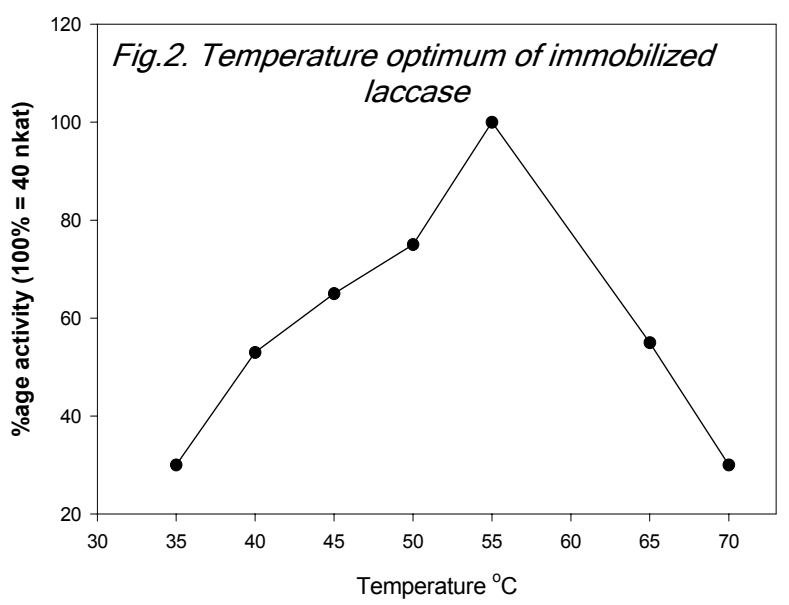

"Immobilized laccase \& Biosensor" http://www.indjst.org phenylenediamine- $\mathrm{HCl}$ and guaiacol. Assay was performed by immersing the single membrane of each type, in $1 \mathrm{ml}$ of buffer containing $200 \mu \mathrm{M}$ concentration of each compound at their respective $\mathrm{pH}$ optimum at $55^{\circ} \mathrm{C}$, reaction time was $10 \mathrm{~min}$, then took $\mathrm{OD}$ at their respective wavelength as described in enzyme assay section.

Sensitivity of immobilized laccase to different analytes

Before determining the response of immobilized laccase to each analyte, the minimum concentration of analyte that could be oxidized under standard assay conditions was determined on the basis of colour development due to enzyme action on the substrate.

Response range of the immobilized laccase

The response of immobilized laccase was checked for syringaldazine, catechol, catechin and L-methyl DOPA. For each reaction, assay was performed at $55^{\circ} \mathrm{C}, \mathrm{pH} 6.0(0.1 \mathrm{M}$, citrate buffer) with separate membrane $\left(1 \mathrm{~cm}^{2}\right)$ laden with immobilized laccase (16 nkat).

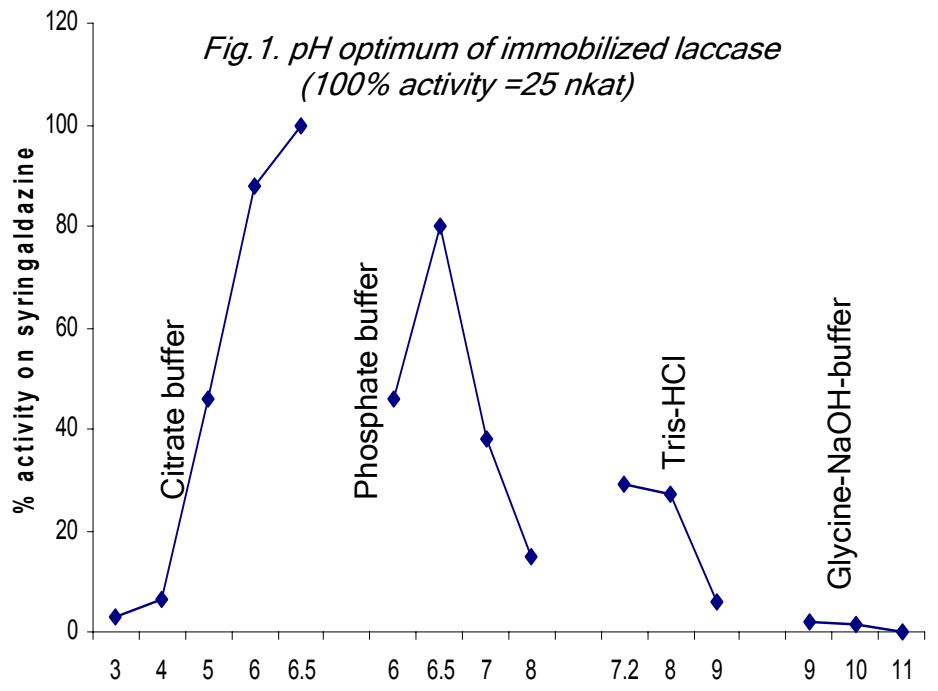

Results

Immobilization of laccase

Partially purified laccase (eluted from DEAESepharose column) immobilized on various supports, showed the following activity order nitrocellulose membrane>Polyvinyl alcohol membrane>guargumagarose membrane and nylon membrane. However, there was no activity in egg shell membrane-immobilized laccase (Table1). Laccase showed $100 \%$ activity after immobilization on nitrocellulose membrane. Therefore, nitrocellulose was Indian J.Sci.Technol. 
chosen as the best support for immobilization. For experimentation, $1 \mathrm{~cm}^{2}$ nitrocellulose membrane with 16 nkat partially purified laccase was used.

\section{Nitrocellulose membrane}

$\mathrm{pH}$ optimum of immobilized laccase was $6.5(0.05 \mathrm{M}$ citrate buffer) on $5 \mu \mathrm{M}$ of syringaldazine at $55^{\circ} \mathrm{C}$. Temperature optimum of immobilized enzyme was $55^{\circ} \mathrm{C}$ $\mathrm{C}$ at $\mathrm{pH} 6.5$ when syringaldazine was used as a substrate (Fig.1 \& Fig. 2).

Shelf life and thermostability of immobilized laccase

Laccase immobilized on nitrocellulose membranes was $100 \%$ stable at $4^{\circ} \mathrm{C}$ to $30^{\circ} \mathrm{C}$ for three months. At $60^{\circ} \mathrm{C}$, immobilized laccase showed only $50 \%$ stabilty after 30 min Fig.3.

\section{Substrate range of immobilized laccase}

Immobilized laccase was active on a wide range of substrates including medically and environmentally important compounds like dopamine, catechin, hydroquinone, syringaldazine, catechol, p-phenylenediamine, guaiacol and ABTS. Immobilized laccase gave best response with syringaldazine which gave reaction even at 1 to $5 \mu \mathrm{M}$ concentration. Immobilized laccase failed to oxidize hydroquinone (Table 2). Laccase was immobilized on $1 \mathrm{~cm}^{2}$ size of nitrocellulose membranes. The membranes gave 1-3\% variation when tested in triplicates.

Response curves of the immobilized laccase to various substrates

Different concentrations ( 1 to $150 \mu \mathrm{M}$ ) of various substrates were used to check the response of immobilized laccase. It was observed that immobilized laccase gave successful response to syringaldazine, catechol, catechin and L-methyl DOPA in the range of 5 to 15,40 to 90,40 to $60 \mu \mathrm{M}, 30$ to $70 \mu \mathrm{M}$ respectively (Fig.4-7). ABTS showed also gave the response to laccase from 0.1 to $0.2 \mathrm{mM}$ (Fig. 8). Response curves of these substrates were used as standard curves for successive measurements of a unknown/known concentration of analyte (above mentioned substrates).

Recycling of immobilized laccase

Laccase immobilized on the nitrocellulose membrane was able to use only once a time not again and again. There was no recycling capability of immobilized laccase.

\section{Discussion}

The use of laccase in biosensor technology is mainly attributed to its broad substrate range allowing for the detection of a wide range of phenolic compounds (Kuznetsov et al., 2001): this does however disallow the detection of specific constituents. Scope of present study was only to evaluate the biosensing potential of a bacterial laccase (from $\mathrm{Y}$-proteobacterium JB). After characterization of immobilized laccase, showed this enzyme is suitable to apply in biosensor fabrication. Nitrocellulose membrane was best source for immobilization because it showed $100 \%$ activity after immobilization of laccase. Immobilized laccase from $y$ - proteobacterium JB also reacted linearly to various substrates even at very low concentration. Moreover immobilized laccase showed thermostability profile as similar to free laccase. Biosensors that utilize laccase include an electrode that may be used for the detection of phenols, such as catechols in tea (Ghindilis et al., 1992), phenolic compounds in wine, and lignins and phenols in wastewaters (Yaropolov et al., 1994). Novel biosensors have been developed using beneficial properties of laccase, such as the potentiometric imunosensor for the detection of antigens (Yaropolov et al., 1994). Immobilization is a proven method of enhancing the stability of enzymes in unfavourable


Research article

CIndian Society for Education and Environment (iSee)
"Immobilized laccase \& Biosensor" http://www.indjst.org
Gursharan Singh et al. Indian J.Sci.Technol. 
conditions (Ahn et al., 2002).

Some times the use of a natural support medium
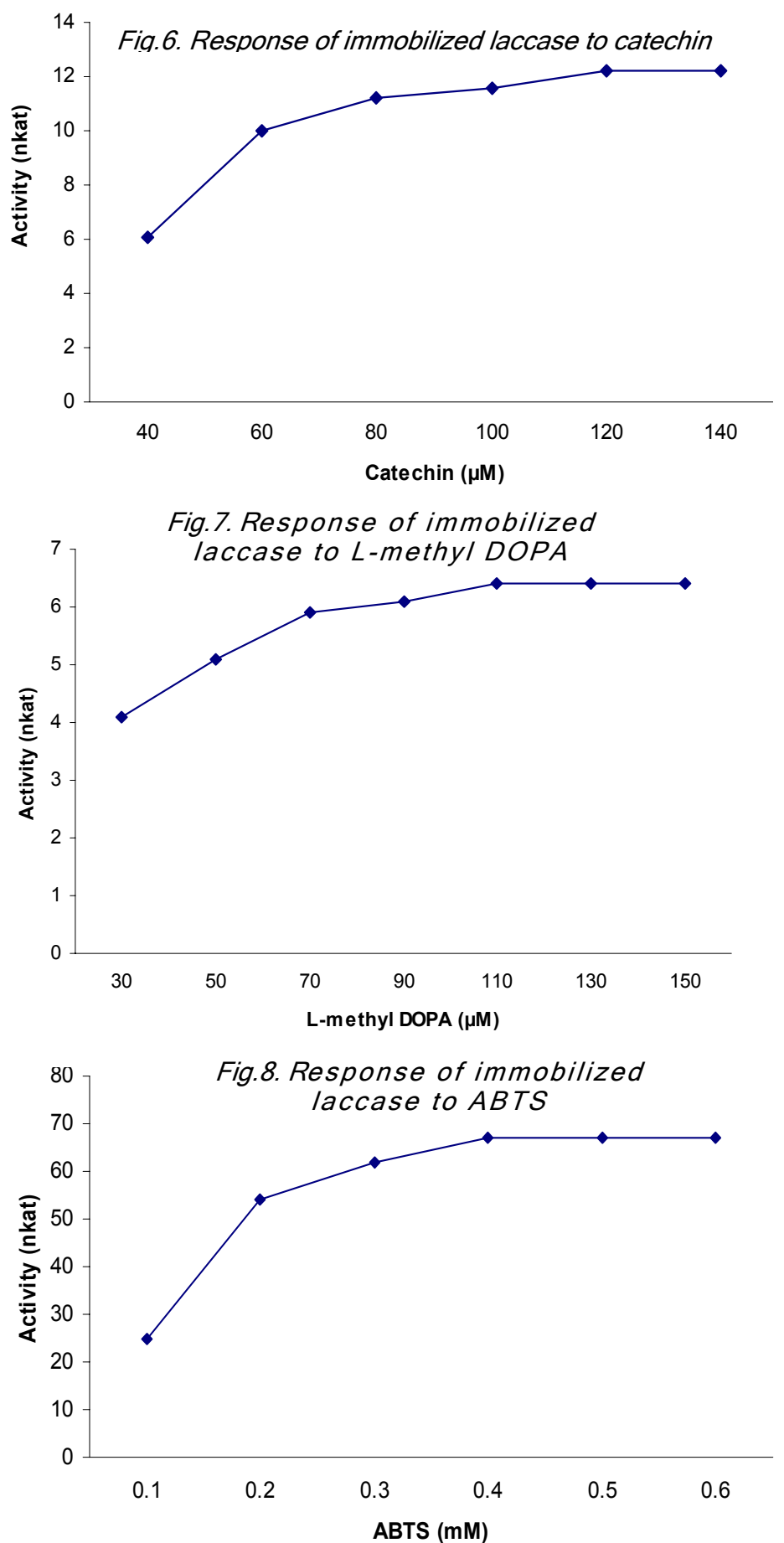

preferable such as clay or soil is desirable since it poses no environmental risk, and is therefore beneficial for terrestrial bioremediation (Ahn et al., 2002). The benefits of immobilization may however be offset by the increased cost and loss of enzyme activity during immobilization (Ahn et al., 2002).

Apart from their industrial use, since laccase oxidation is coupled with the reduction of dioxygen, these enzymes were also employed as a cathode "active" material in biofuel cells. The effective use of an enzyme can be enhanced by its immobilization on a solid support.

This structural motif results in operational stability and durability of the enzyme with the aim of cost reduction particularly for, e.g., continuous processes or by reuse of the enzymes. Laccases were usually immobilized in porous materials like glass or clays, physically adsorbed on electrode surfaces or covalently bound to the surface, typically with glutaraldehyde or carbodiimide chemistry (Mazura et al., 2007). The method by which an enzyme is immobilized at any surface or matrix is a critical factor in providing a flexible yet stable layer of the bioactive species in a form that maintained its native behaviour. Moreover, the surfaceattachment chemistry should provide the proper orientation of an enzyme to establish efficient electronic contact between such an enzyme and the matrix surface. Yinghui et al. (2002) reported that, laccase was immobilized on carboxylated polyvinyl alcohol (PVA) activated by $\mathrm{N}$-hydroxysuccinimide $(\mathrm{N}-\mathrm{HSI})$ in aqueous solution at different $\mathrm{pH}$, temperature, and with different reaction period and also found optimum condition for laccase immobilization was at $\mathrm{pH} 3.2,40^{\circ} \mathrm{C}$ and $12 \mathrm{~h}$, respectively. In case of laccase from $\gamma$-proteobacterium JB immobilization was best at $\mathrm{pH} 6.0$, at wide range of temperature $\left(4-40^{\circ} \mathrm{C}\right)$. Seok et al., (2008) reported that purified laccase was immobilized on the silanized porous glass beads (200-400 mesh), Supp1, Supp2 and Supp3, after activation with glutaldehyde which showed the highest activity at $60^{\circ} \mathrm{C}$. However, the activity of immobilized enzyme was higher than that of the free enzyme at the same temperature. All immobilized enzymes were relatively stable at the wide range of temperature $\left(50^{\sim} 80^{\circ} \mathrm{C}\right)$ compared to the free enzyme.

Among the matrices tried for the immobilization of laccase, nitrocellulose membrane was the most suitable with the substrates and gave best results. The biostrips of nitrocellulose were stable at room temperature for nearly one year when stored under dry conditions at $4^{\circ} \mathrm{C}$. Our immobilization method has following advantages over various matrices reported in literature (1) inexpensive starting materials, (2) a rapid simple method and (3) improved stability at low temperatures.

Table 2. Activity profile of immobilized laccase (16 nkat) on nitrocellulose membrane

\begin{tabular}{|l|c|}
\hline Substrate & Activity (nkat) \\
\hline Syringaldazine & 15 \\
\hline ABTS & 11 \\
\hline Guaiacol & 05 \\
\hline Catechol & 04 \\
\hline Hydroquinone & ND \\
\hline L-methyl DOPA & 05 \\
\hline Catechin & 07 \\
\hline p-Phenylenediamine & 05 \\
\hline
\end{tabular}

$\mathrm{ND}=$ not detectable

Gursharan Singh et al. Indian J.Sci.Technol.
Research article

CIndian Society for Education and Environment (iSee)
"Immobilized laccase \& Biosensor" http://www.indjst.org 


\section{References}

1. Ahn MY, Dec JE and Bollag (2002) Treatment of 2,4dichlorophenol polluted soil with free and immobilized laccase. J. Environ. Quality. 31,1509-1515.

2. Bains J, Capalash N and Sharma P (2003) Laccase from a non melanogenic, alkalotolerant $\gamma$ proteobacterium JB isolated from industrial waste water drained soil. Biotechnol. Lett. 25, 1155-1159.

3. Bourbonnais R, Paice MG, Freiermuth $B$ and Borneman S (1997) Reactivities of various mediators and laccases with kraft pulp and lignin model compounds. Appl. Environ. Microbiol. 63, 4627-4632.

4. Degryse E, Glandsdorff N and Picrard A (1978) A comparative analysis of extreme thermophilic bacteria belonging to the genus Thermus. Archives Microbiol. 117, 189-196.

5. Duran N and Esposito E (2000) Potential applications of oxidative enzymes and phenoloxidase-like compounds in wastewater and soil treatment: a review. Appl. Catal. B Environ. 28, 83-99.

6. Ghindilis AL, Gavrilova VP and Yaropolov Al (1992) Laccase-based biosensor for determination of polyphenols: determination of catechols in tea. Biosensor Bioelec. 7(2), 127-131.

7. Gianfreda L and Xu F. Bollag (1999) Laccases: a useful group of oxidoreductive enzymes. Bioremediation. 3, 1-25.

8. Givaudan A, Effosse A, Faure D, Potier P, Bouillant ML and Bally R (1993) Polyphenol. Polyphenol oxidase from Azospirillum lipoferum isolated from rice rhizosphere: evidence of laccase activity in nonmotile strains of Azospirillum lipoferum. FEMS Microbiol. Lett. 108, 205-210.

9. Hullo MF, Moszer I, Danchin A and Martin-Verstraete (2001) Cot A of Bacillus subtilis is a copperdependent laccase. J. Bacteriol. 183, 5426-5430.

10. Kumaran S and Morita M (1995) Application of a cholinesterase biosensor to screen for organophosphorous pesticides extracted from soil. Talanta. 42 (4), 649-655.

11. Kuznetsov BA, Shumakovich GP, Koroleva OV and Yaropolov Al (2001) On applicability of laccase as label in the mediated and mediator less electroimmunoassay: effect of distance on the direct electron transfer between laccase and electrode. Biosensor Bioelectron. 16, 73 -84.

12. Mateo JM, Gloria $P$, Fernandez-Lorente and Fernandez-Lafuente (2007) Improvement of enzyme activity, stability and selectivity via immobilization techniques. Enz. Microb. Tech. 40, 1451-1463.

13. Mazura MP, Krysiński A, Michota-Kamińska, Bukowska J, Rogalski G and Blanchard (2007) Immobilization of laccase on gold, silver and indium tin oxide by zirconium-phosphonate-carboxylate (ZPC) coordination chemistry. Bioelectrochem. 71, 15-22.
Vol. 3 No. 1 (Jan 2010)

ISSN: 0974- 6846

14. Sanchez-Amat A and Solano F (1997) A pluripotent polyphenol oxidase from the melanogenic marine Alteromonas sp. shares catalytic capabilities of tyrosinases and laccases. Biochem. Biophys. Res. Commun. 240, 787-792.

15. Seok N, Hee-Yeon, Soo-Jeong S, Yun-Jeong, Leonwicz A and Ohga S (2008) Production of fungal laccase and its immobilization and stability. Fac. Agri. Kyushu Univ. 53 (1), 13-18.

16. Sharma P, Goel R and Capalash N (2007) Bacterial laccases. World J. Microbiol. Biotechnol. 23, 823-832.

17. Sharma SK, Sehgal N and Kumar A (2002) A quick and simple biostrip technique for detection of lactose. Biotechnol. Lett. 24, 1737-1739.

18. Singh G, Ahuja N, Batish M, Capalash $N$ and Sharma $P$ (2008) Biobleaching of wheat straw-richsoda pulp with alkalophilic laccase from $\gamma$ proteobacterium JB: Optimization of process parameters using Response Surface Methodology. Biores. Technol. 99, 7472-7479.

19. Singh G, Capalash N, Goel R and Sharma P (2007) A $\mathrm{pH}$-stable laccase from alkali-tolerant $\gamma$ proteobacterium JB: Purification, characterization and indigo carmine degradation. Enz. Microb.Technol. 41, 794-799.

20. Tembe S, Inamdar S, Santosh H, Karve S F and D' Souza (2007) Electrochemical biosensor for catechol using agarose-guar gum entrapped tyrosinase. $\mathrm{J}$. Biotechnol. 128, 80-85.

21. Wen G, Zhang $Y$, Zhou $Y$, Shuang S, Chuan D and Martin M (2005) Biosensors for determination of galactose with galactose oxidase immobilized on eggshell membrane. Anal. Lett. 38,1519-1529.

22. Xu F (2005) Applications of oxidoreductases: Recent progress. Industrial Biotechnol. 1, 38-50.

23. Yaropolov Al, Skorobogat'ko SS and Varfolomeyev (1994) Laccase: Properties, catalytic mechanism, and applicability. Appl. Biochem. Biotechnol. 49, 257-280.

24. Yinghui D, Qiuling W and Shiyu F (2002) Laccase stabilization by covalent binding immobilization on activated polyvinyl alcohol carrier. Lett. Appl. Microbiol. 35, 451-456. 